April 2008

\title{
The United States' Response to Genocide in the Independent State of Croatia, 1941-1945
}

Rob McCormick

Follow this and additional works at: https://digitalcommons.usf.edu/gsp

\section{Recommended Citation}

McCormick, Rob (2008) "The United States' Response to Genocide in the Independent State of Croatia, 1941-1945," Genocide Studies and Prevention: An International Journal: Vol. 3: Iss. 1: Article 6.

Available at: https://digitalcommons.usf.edu/gsp/vol3/iss1/6

This Articles is brought to you for free and open access by the Open Access Journals at Digital Commons @ University of South Florida. It has been accepted for inclusion in Genocide Studies and Prevention: An International Journal by an authorized editor of Digital Commons @ University of South Florida. For more information, please contact digitalcommons@usf.edu. 


\title{
The United States' Response to Genocide in the Independent State of Croatia, 1941-1945
}

\author{
Rob McCormick \\ University of South Carolina Upstate
}

\begin{abstract}
In April 1941, Ante Pavelic', the fascist leader of the Independent State of Croatia, and his paramilitary force, the Ustase ("rebels"), began a genocide that killed at least 330,000 Serbs and essentially eliminated Jews and Roma from Croatia. The American response to genocide in Croatia provides a fuller context for examining Washington's reaction to the Nazi genocide. By the summer of 1941, the US government had reliable information that genocide was taking place in Croatia. Washington expressed little interest in this slaughter, except insofar it affected Croatian-American and Serbian-American relations; made no direct public statement condemning the Ustaše's actions; and offered no protest to the Vatican. Croatian events, however, propelled the FBI and the Office of War Information to suppress pro-Ustaše supporters in the United States.
\end{abstract}

Keywords: Croatia, genocide, United States, Ante Pavelić, State Department

For much of World War II, a substantial amount of the US State Department's information about Croatia originated in Ankara and Istanbul. Neutral Turkey, situated at an important crossroads for Germany, Britain, the United States, and the Soviet Union, was an excellent location for mischief and fact finding. All belligerents found it a convenient playground for cloak-and-dagger operations, as well as a more innocuous center for information gathering. On 6 May 1941, a disturbing telegram, which foreshadowed future events, arrived in the State Department from the American embassy in Ankara. Rushed to Washington, the telegram contained information gained from Yugoslav contacts. The alarming message read, "according to dependable information partizans of Pavelić (in some cases in conjunction with Magyars) are massacring Serbs in Croatia, the Voyvodina and Bosnia. There is need of urgent intervention by the Vatican at Zagreb and Budapest." ${ }^{1}$ The intervention so desperately sought never materialized. No one came to the aid of Serbs, Jews, and Roma who suffered so mightily under Ante Pavelić's reign in the alleged Independent State of Croatia. This telegram was the first report received in Washington that spoke of the slaughter, which eventually reached catastrophic proportions. By the end of the war, Pavelić and the Ustaše (the paramilitary force he founded in 1929) had murdered between 330,000 and 390,000 Serbs, many of whom were tortured and executed in the most despicable manner. ${ }^{2}$ Tens of thousands were forced to convert, often at gunpoint, from Orthodoxy to Catholicism. The Jewish and Roma populations, substantially smaller, were all but eliminated.

Historians have paid little attention to America's role in confronting Ante Pavelić's killing spree. ${ }^{3}$ Much has been written about Washington's response to Nazi mass murder, but the Independent State of Croatia (Nezavisna Država Hrvatska, or NDH) 
has been left out of this discussion. Historians have given only a passing glance at America's views of and policy toward Croatian wartime atrocities. Washington's reaction to atrocities in Croatia offers an interesting case study and provides a fuller context for evaluating America's reaction to World War II genocide. Although policymakers learned of the Independent State of Croatia's massacres at an early date, the evidence of the slaughter did not move them to significant action. The White House and the State Department made no detailed and direct public statements about the atrocities being perpetrated in the NDH. Even with accurate information in hand, much of it arriving early in the course of the genocide, officials in Washington chose to remain aloof.

It is easy to criticize American officials for failing to publicly decry the atrocities in the NDH or to attempt in any significant way to influence Pavelić's regime. Regardless of the vivid and often thorough reports of mass slaughter, American officials offered few internal or external comments about these atrocities, even after the United States entered the war. With a strong current of non-intervention and nativism focusing attention on domestic issues, one can understand why policy makers made the decisions they did. Policy toward the atrocities was dictated by the need to limit ethnic tension between Serbian Americans and Croatian Americans. The American government was concerned that the crisis in Croatia had the potential to foster violence in the United States that would weaken the domestic war effort, especially in heavy industry, where Yugoslav immigrants tended to work. This was a highly practical way of responding to atrocities in a small, distant land that only rarely garnered American attention.

\section{The Ustaše}

To fully appreciate American response to the atrocities in the Independent State of Croatia, one must examine Ustaše ideology and the activities of the organization once it gained power in Croatia. The ideological foundation of the Ustaše reaches back to the nineteenth century, when Ante Starčević established the Party of Right. Starčević, a stalwart opponent of the Austro-Hungarian Empire, consistently favored Croatian independence and rejected any idea of a Yugoslavia, as supported by Bishop Josip Strossmayer. Josip Frank was the heir to Starčević's gospel, but Frank reversed a key aspect of Starčević's views: hoping to elevate Croatia's political prestige in the Dual Monarchy, Frank's Pure Party of Rights supported the regime. Although there were different opinions about Croatia's role in the Habsburg Empire, Frank's party embraced Starčević's view that Serbs were the enemy of Croatian political and territorial ambitions. As time passed, aggressively anti-Serbian views became the hallmark of the Pure Party of Rights. With the collapse of the Dual Monarchy and the creation of Yugoslavia, Frank's party descended deeper into its anti-Serbian and antiOrthodox positions. They were fervent opponents of the centralist 1921 constitution, believing that the document extinguished hope for Croatian independence while ensuring Serbian hegemony in the new state. In this they were not alone. The Croatian Peasant Party, the political voice for the majority of Croatians, also opposed the 1921 constitution. ${ }^{4}$

Those in tune with Frank's violent anti-Serbian positions found a unifying voice in Ante Pavelić. A native of Bradina, Pavelic emerged in the 1920s as the leading spokesman for Croatian independence. Fully embracing the anti-Serb views of Starčević and Frank, and believing that a professional revolutionary organization was needed if Croatia were to gain its independence, Pavelić, a lawyer by training, established the Ustaše along the lines of Bulgaria's infamous Internal Macedonian 
Revolutionary Organization (IMRO). From its inception in 1929, the Ustaše was violent and revolutionary. ${ }^{5}$ Their beliefs were a collection of seemingly disparate ideologies bound together in one movement. In this way, they hoped to attract a wide variety of followers. In Ustaše ideology, one could be a proto-fascist and, at the same time, a deep believer in Catholicism. At its ideological core was a fervent, mystical belief in the holiness and sanctity of the Croatian state. As Ustaše's architect, Pavelić maintained that Croatians had established a state 1,400 years earlier and that, over the centuries, they had never abandoned their right to independence. Regardless of the Ottomans, the Habsburgs, or the Karadjordjevićs, Croatia had always existed. Therefore, Pavelić's chief goal was the resurrection of an independent Croatian state with borders corresponding to earlier manifestations of Croatia. This objective was achievable only through the destruction of Serbian-foreigninfluence within Croatia, which, in turn, necessitated the annihilation of Yugoslavia. Correspondingly, the well-being of the state was of such significance that individual rights ran a distant second to the establishment and maintenance of Croatia. Pavelićs fascist tendencies were apparent. ${ }^{6}$

In their desire to demonstrate the distinctiveness of their people, the Ustaše deemed Croatians of pure peasant stock a separate nationality from their Balkan neighbors. By the beginning of World War II, Ustaše ideologues would proclaim that Croats were Goths, and therefore of Germanic origin, far removed from the inferior Slavic Serbs. Any myth could be used to separate Croatians from Serbs. Like the Nazis, the Ustaše placed the peasant on a pedestal, extolling his virtues of clean living and hard work. The peasant was nearly incorruptible, and there was much discussion of establishing a peasant republic. Both Nazi and Croatian currency during World War II featured images of the solid and pure peasant. Pavelic, though he believed in the virtues of the peasant, was a clever politician who judged that such depictions would attract disenchanted peasants to his cause while weakening the Croatian Peasant Party.

Another key aspect of Ustaše ideology was a deep-seated commitment to the Catholic faith. As a devoted Catholic, Pavelić believed that Croatians had been chosen by God to defend Catholicism against assaults from both Orthodoxy and Communism. This religious zeal, which held no tolerance for Orthodoxy, helped provide a spiritual appeal to the Ustaše movement. According to Pavelić and his minions, Croatians had been warriors and martyrs for Christianity and needed to continue the good fight for their independence, which would only strengthen them as the "bulwark of Christianity." This fervor enabled Pavelic to successfully demonize Serbs. He did not despise Serbs simply because they were a different ethnic group, one that had exercised power over all of Yugoslavia for the past decade, but also because they embraced Orthodoxy, a foreign faith that, the Ustaše believed, was encouraged by the Serbian-dominated Yugoslavian government. Thus Orthodoxy was viewed as a tool for smashing Croatian national identity. Likewise, communists, who were on the march in the 1920 s and $1930 \mathrm{~s}$, were mortal foes of Catholicism and had to be stopped. ${ }^{7}$ To the Ustaše, Croatians faced both political and religious enemies who were determined to destroy Croatian culture, its traditions, its language, its political life, and its religion. In other words, Ustaše ideology encouraged something akin to a holy war.

Perhaps the best description of Ustaše sentiment came during World War II from a Lieutenant Miloš, an Ustaše guard. Speaking to Vladko Maček, the leader of the Croatian Peasant Party and his prisoner, about the terrible murders of Serbs, Miloš justified his and the Ustaše's actions by saying, "I am perfectly aware of what is in 
store for me. For my past, present and future deeds I shall burn in hell, but at least I shall burn for Croatia." 8 Such extreme nationalistic zealotry was the foundation for a loyal core of Ustaše.

After King Aleksandar's coup in January 1929, Pavelić, fearing arrest, fled Yugoslavia and proceeded to organize the Ustaše. His recruiting efforts, coupled with his publicly admitted goal of overthrowing the Yugoslav state, forced Belgrade to convict him of treason and hang the death penalty over his head. Not in the least deterred, Pavelić stepped up his recruiting efforts. Hoping to create absolute loyalty and esprit de corps, he required all members to swear allegiance to himself and to the independence of Croatia in an elaborate ceremony that included a knife, a revolver, and a crucifix. The Ustaše's motto, Za Dom Spremni ("Ready for the Fatherland"), was meant to rally his followers into fighting for an independent Croatia. Pavelić's recruiting efforts, however, achieved only modest results, since most Croatians were repelled by his radical demands and his willingness to use violence. The majority of Croatians followed Maček of the Croation Peasant Party, who, although lacking in glamor, was seen as the only realistic option for gaining Croatian autonomy. Unable to recruit many followers, the Ustaše remained a fringe operation with little support within Yugoslavia. It survived by attracting thugs, the highly impressionable, and the unemployed. By 1934, Pavelić had amassed an army of perhaps 500 to 600, mostly disenchanted ne'er-do-wells. Though his numbers were small, Pavelić had established an organization of men willing to sacrifice their lives for the Ustaše cause.

The Ustaše scored a significant success in 1934, when Pavelic planned the successful assassination of King Aleksandar I of Yugoslavia in Marseilles. This audacious crime attracted worldwide attention, but it did not lead to the dismemberment of Yugoslavia, as Pavelić had hoped. Having received his second death sentence, this time from a French court, Pavelic spent the remainder of the 1930s in Benito Mussolini's Italy. Often Pavelić's protector, Il Duce believed that Pavelić was a destabilizing force for Yugoslavia, who could be useful to Italian interests if Yugoslavia were divided into its constituent parts. Mussolini hoped that Italy would one day gain the Dalmatian coast that had been promised to it in the 1915 Treaty of London. ${ }^{9}$

Internally, tensions between Serbs and Croats continued to spell trouble for Yugoslavia. Prince Paul and Vladko Maček signed the the sporazum (agreement) of 20 August 1939, hoping that it would quell unrest between Serbs and Croats and thus strengthen Yugoslavia. This agreement provided for an autonomous Croatia within Yugoslavia. Under the sporazum, Zagreb controlled its internal affairs through a sabor (assembly) and a ban (governor), while Belgrade remained paramount in foreign policy, defense, and the like. The sporazum, however, did little to solve the ethnic problems. Muslims and Serbs who now found themselves under a Croatian government feared for their rights, believing that Belgrade had abandoned them. Likewise, Pavelić and the Ustaše opposed the sporazum, calling it another attempt by Serbs to dominate Croatians. They argued that the accord did not go far enough, since it excluded Bosnia-Herzegovina from Croatian control and allowed for too much authority from Belgrade. Pavelić insisted that no agreement was possible and that the only solution was independence. His views were little more than sour grapes, because the agreement was certainly a step in the direction desired by the majority of Croatians. Although the sporazum was a noble attempt to unify Yugoslavia, it was too little too late. The result was a more deeply divided Yugoslavia.

With war clouds descending over Europe, the sporazum never had an opportunity to gain momentum. As the Third Reich extended its dominance over the continent, 
German ambitions began to dictate policy in Eastern Europe. It was only a matter of time before Yugoslavia would have to choose whether or not to throw in its lot with the Nazis. After Bulgaria joined the German camp on 1 March 1941, it was apparent that Yugoslavia was going to sign the Tripartite Pact, regardless of political pressure from Western nations. Prince Paul, Yugoslavia's regent, believed that his signature, with a bit of luck, would preserve some degree of independence and avoid bloodshed. Yugoslav officials negotiated clauses that stipulated only political affiliation and did not mandate military ties, a point that had no validity in Berlin. As Germany gained influence in Bulgaria and pressure over the Italian debacle in Greece mounted, placing Yugoslavia in an untenable position, Prime Minister Dragiša Cvetković and Prince Paul joined the fascists by signing the Tripartite Pact on 25 March 1941 in Vienna.

As this crisis was brewing in 1941, President Franklin Roosevelt, in conflict with the State Department's wishes, began to show an interest in Yugoslavia. Before Yugoslavia signed the Tripartite Pact, Roosevelt sent William "Wild Bill” Donovan on a fact-finding mission into the Balkans, on the outside chance that Donovan could help create a Balkan front against German aggression. ${ }^{10}$ Although such a policy was far from feasible, Roosevelt realized that Yugoslavia and the Balkans in general were an important factor in the drive to stymie German expansion. The president went so far as to promise Yugoslavia access to Lend-Lease if it remained independent of Germany's clutches. This was not a significant carrot for Yugoslavia, however, with the United States thousands of miles away and Germany on their doorstep. When Paul signed the Tripartite Pact, Roosevelt immediately showed his displeasure by ordering that all Yugoslav assets in the United States be frozen. The regent had done what he believed was right for Yugoslavia.

The Yugoslav government, however, had signed its own death warrant, as Yugoslavs erupted in protest against the Tripartite Pact. Cvetković's government lasted for only two more tumultuous days, both full of demonstrations against Germany and demands for the government's resignation. The Yugoslav military, which leaned toward the Western Allies, could not stomach joining the Tripartite Pact, believing it spelled the end of Yugoslavia and placed them squarely in the camp of their long-term enemies. With the British urging a coup d'état, the military overthrew the government and established a new regime, under General Dušan Simović, in the name of eighteen-year-old King Peter II. In a lightning stroke, fascism was rejected, the regency had ended, and young Peter was king.

The US State Department was jubilant over this turn of events and ordered its minister to Yugoslavia, Arthur Bliss Lane, with great haste, to express America's approval of the coup. Lane was directed to proclaim that "this event constitutes a matter for self-congratulation for every liberty-loving man and woman."11 Washington wanted the new government to know that,

in accordance with the provisions of the Lend-Lease Bill, the President, in the interest of the national defense of the United States, is enabled to provide assistance to Yugoslavia, like all other nations which are seeking to maintain their independence and integrity and to repel aggression. ${ }^{12}$

Obviously Roosevelt wished to continue the policy of promising military equipment to Yugoslavia in return for a continued stand against Germany.

By all accounts, Hitler was furious at the coup and demanded that Yugoslavia be crushed. The Führer was certain that Yugoslavia would easily collapse under German military might, judging that the Croatians would side with Berlin against Belgrade. Hitler was correct in his estimation. As Ulrich von Hassell, former German 
ambassador to Rome, commented during his visit to Zagreb in March 1941, "Freundt (German Consul in Agram) and all Croats with whom I spoke emphasized the great differences between Croatia and Serbia. In Croatia there is no opposition whatever to Germany (with a few exceptions); on the contrary, a desire to co-operate."13

On 6 April 1941, German forces invaded Yugoslavia; in a matter of days, Yugoslavia was defeated. With the approval of Berlin, Mussolini quickly moved to install Ante Pavelic as the poglavnik of the alleged Independent State of Croatia. ${ }^{14}$ Pavelić, with a small number of devoted Ustaše, entered the new satellite state on 13 April.

\section{Genocide}

Upon gaining power, Pavelić wasted no time in attacking Serbs, Jews, Roma, and Croatians who opposed the NDH. His initial step was to protect the NDH by eliminating all who spoke out against it, while placing all non-Croatians on the fringes of society by revoking their citizenship. Similar to Jews in the Third Reich, Orthodox citizens were required to wear blue armbands bearing the letter $P$, for Pravoslavac (Orthodox). Meanwhile, the Cyrillic alphabet was prohibited on 25 April 1941, an act designed to destroy Serbian identity and transform those Serbs deemed most pliable into Croatians. All schools operated by the Orthodox Church were closed. Serbs were banned from Croatian businesses and denied access to public events such as films and concerts. Over time, Serbian private property was confiscated, much of it going directly to the NDH leadership. ${ }^{15}$

The Ustaše's position on citizenship, made clear in the Law Concerning Nationality, provided the legal foundation for ending the non-Croatian presence in the NDH. Decreed by Pavelic on 30 April 1941, this law stated that

a citizen is a national of Aryan origin who has proven by his conduct that he did not engage in activities against the liberation efforts of the Croatian people and who is ready and willing to serve faithfully the Croatian nation and the Independent State of Croatia. $^{16}$

This sweeping edict effectively reduced all Serbs, Jews, and Roma, as well as any Croatians who had opposed independence or the NDH, to the status of aliens residing within Croatia. The law fit perfectly with the Ustaše's position that Croatia should be ruled and inhabited only by "pure" Croatians, those who supported the NDH.

What gave added strength to the above-mentioned edicts was the broad Law on the Protection of the People and the State, issued by Pavelic on 17 April, which decreed that

whoever in any way does or has done harm to the honor and vital interests of the Croatian nation or who endangers in any way the existence of the Independent State of Croatia or its government authorities, shall be considered guilty of high treason, even if his act was but a mere attempt. ${ }^{17}$

Acts of treason were punishable by death. In essence, the law gave the NDH carte blanche to arrest and execute anyone who opposed the state in any way. Since it was retroactive, it could even be used against those who opposed the Ustaše before they came to power. Execution was meted out summarily to those who were found guilty of violating the law by hastily organized "People's Courts."18

Beginning in the spring and summer of 1941 and continuing until the end of the war, Pavelić and his henchmen unleashed a reign of terror rarely paralleled in history. A veritable murderous frenzy possessed the Ustaše, whose goal, according to an 
infamous statement by Mile Budak, minister of education and doglavnik (second to Pavelić), was to "convert a third, expel a third and kill a third" of the Serbs. ${ }^{19}$ Budak, a well-known novelist and journalist and an outspoken Ustaše supporter, publicly outlined this policy in Gospić on 22 June. According to Budak's plan, Serbian culture would be eliminated from Croatia either by extermination, exile, or assimilation.

And so began a killing spree designed to purify the new Croatia. The Ustaše's viciousness shocked even Nazi observers. Describing the horror, the late Irish historian Jonathan Steinberg wrote,

Serbian and Jewish men, women and children were literally hacked to death. Whole villages were razed to the ground and the people driven into barns to which the Ustasi set fire. There is in the Italian Foreign Ministry archive a collection of photographs of the butcher knives, hooks and axes used to chop up Serbian victims. There are photographs of Serb women with breasts hacked off by pocket knives, men with eyes gouged out, emasculated and mutilated. ${ }^{20}$

Serb men, women, and children were pushed from cliffs, plunging to their deaths. Whole villages of Serbs were annihilated. Unlike Germany's systematic executions, often conducted in a clinical and sterile fashion, the Ustaše reveled in their bloodlust, employing various acts of torture such as skinning and burning victims alive. Sexual mutilation was far from unknown and was embraced by the especially wicked. Some Serbs were hacked to pieces, with their noses, ears, and tongues cut off. These techniques were often meted out to Orthodox priests, the Ustaše's most hated enemy. There was little effort to bury the dead, unless victims had previously dug their own graves at gunpoint. Often, Ustaše victims were left to rot in the open; sometimes they were tossed into the Sava River. Such unspeakable acts were commonplace. ${ }^{21}$

In Glina, for example, about 600 Serb men, women, and children were shot, stabbed, and beaten to death in their Orthodox church, which was subsequently burned. The murders continued unabated throughout the summer of 1941. Konstantin Fotić, Yugoslavia's minister to Washington, wrote that

Thousands of corpses were dumped into the Sava River, which flows into the Danube at Belgrade, with the inscription "Visa for Serbia" on tags around their necks. The river... became so contaminated by these corpses that access to its beaches was prohibited by the German occupiers during the whole summer of $1941 .^{22}$

In June 1941, the NDH began deporting selected Serbs from Croatia. They created the Državno Ravnateljstvo (State Directorate for Renewal), which established camps designed to assemble Serbs for resettlement. It did not take long before these camps, rife with disease as a result of poor sanitation and notorious for brutal treatment, became, in effect, death camps. To the casual observer, they did not look much like camps; instead, they resembled cattle pens. There were few barracks, and those that existed offered little sanctuary from the elements. Serbs were tossed into barbed-wire enclosures and forced to live in deplorable conditions. The $\mathrm{NDH}$ had no desire to resettle anyone; their ambition was to kill. The Serbs who did not die from exposure or malnutrition were executed by other means, such as axe blows and shooting. The openair camps merely aided the execution process.

The most infamous of all the camps was Jasenovac, where thousands of men, women, and children were butchered with bullets, axes, hammers, and any other instrument available. ${ }^{23}$ Built in a low-lying flood plain, Jasenovac was established in August 1941 and quickly grew into the third-largest concentration camp in Europe. In fact it was a series of five camps, located along the Sava River south of Zagreb. Jasenovac was the Croatian Auschwitz: torture and execution were daily occurrences 
for Jews and Serbs alike, and guards needed only the flimsiest of excuses to shoot prisoners. The chief execution site was at Gradina, where thousands were killed by Ustaše guards. Like German-operated camps, Jasenovac discriminated on arrival between useful prisoners and those deemed suitable only for execution. Those without needed skills were summarily killed shortly after arriving in the camp, while those who were allowed to live endured a slow death from strenuous labor, malnutrition, physical abuse, and unsanitary living conditions. Anyone hardy and skillful enough to survive longer than three months was summarily executed, in accordance with camp rules. $^{24}$

Although Ustaše ideology directed the greatest attention toward the Serbs, Pavelić wasted little time in unleashing brutal attacks on Jews, chiefly because he recognized that he had to satisfy Hitler and the Nazis in order to remain in power. Like the Serbs, the Jews were rounded up by the NDH beginning in the summer of 1941. Following Hitler's lead, the NDH stripped Jews of their citizenship and property, forced them to wear a yellow star armband, forbade them to marry gentiles, and removed them from all government positions. Before the end of 1941, most were well on their way to extermination. The Jewish community in Sarajevo, which totaled about 10,000, was an early and easy target. By the end of 1942, Sarajevo's Jews and most other Jews either were confined to concentration camps or had been executed. Most of Zagreb's approximately 10,000 Jews avoided the death camps until $1944 .^{25}$ The Ustaše enjoyed great success in abolishing the Jewish presence in Croatia by killing all but a few thousand Jews, confiscating all their private property, and destroying almost all the synagogues in the country. Hitler and his henchmen were more than satisfied with their understudy's treatment of Croatian Jews.

Since Raphael Lemkin coined the term "genocide," controversy has swirled about applying the term to particular atrocities. ${ }^{26}$ Soon after World War II ended, the Yugoslav government, recognizing that ethnic hatreds emerging from the war had the capacity to destabilize the new Communist regime, tried to paper over wartime atrocities, hoping to establish a Yugoslav identity. Although the goal was to mask specific ethnic losses by extolling the dead, collectively, as victims of fascism, it did not take long for nationalism-driven figures to re-emerge, seeking to address wartime atrocities. Those killed by the NDH became a political football used by Serbian nationalists to attack all Croatians as enemies of Serbia and Yugoslavia. Serb victims of the Ustaše became symbols of Serb suffering and martyrdom that complemented the theme of romanticized suffering, an important component of Serbian history. In this way, Serbian history could be interpreted through the mythology created around such events as the defeat at the Battle of Kosovo in 1389 and the heroic retreat through Albania during World War I. Even today, the Kosovo question resonates in a similar fashion. As Croatian national identity reemerged in the 1960s, Croatian nationalists sought to minimize the events in the NDH, explaining Serbian accusations of genocide as out of context and exaggerated. ${ }^{27}$ Croatians wanted to turn attention toward the Bleiberg Massacre, when British troops returned Croatians to Yugoslavia to be slaughtered by Tito's Partisans. Through a denial of the extent of Ustaše crimes, Croatian history could be safely rescued from the blemish of genocide and refocused on the new paradigm of a long, noble history of fighting for independence. Even Ante Pavelic could be rehabilitated as a hero of Croatian independence. ${ }^{28}$ During the warfare of the 1990s, focus on the NDH's atrocities reached its apex, and the atrocities of World War II were used extensively by both sides to justify all kinds of horrific acts. $^{29}$ This heated debate between Croatian and Serbian camps has made it difficult 
for historians to develop a sober understanding of the NDH atrocities perpetrated during World War II.

If one examines the standard for genocide outlined by the 1948 UN Convention on the Prevention and Punishment of the Crime of Genocide (UNCG), Ustaše murders meet the criteria. ${ }^{30}$ But this standard has received much criticism for being too narrow and much too obtuse. Over the last several years, numerous scholars have devoted themselves to studying the problematic nature of the UNCG, while sometimes providing or calling for a definition of genocide. ${ }^{31}$ Crafting such a definition has been difficult, often politically charged. By most of these definitions, especially those established by Ben Kiernan, Helen Fein, and Robert Melson, the Ustaše were guilty of genocide. $^{32}$ Ante Pavelić targeted Serbs as a specific ethnic group; NDH policies initiated the campaign to destroy the Serbian presence in Croatia, including its historical legacy.

There is precedent for calling NDH atrocities "genocide." Edmond Paris, in 1961, was the first author to term the Ustaše slaughters "genocide"; Paris's version of events, though emotionally driven and lacking in context and perspective, brought attention to atrocities in the $\mathrm{NDH}^{33}$ Since that time, several historians, devoid of nationalist sentiments and emotional judgments, have applied the term to the events in the NDH. In 1968, John A. Armstrong wrote that "genocide, in the most literal sense of the term, was the Ustasa 'final' solution." 34 In Accounting for Genocide, Helen Fein agrees with other historians that the atrocities in the NDH were genocide. ${ }^{35}$ Leo Kuper has echoed these sentiments; Kuper calls Ustaše actions "genocide," explaining that they "arose out of a long history of conflict between Croats and Serbs, fuelled later in the newly constituted state of Yugoslavia by Croatian resentment of Serbian hegemony and repression."36 Other notable scholars such as Bette Denich, Robert Hayden, and Michael Sells have used the term "genocide" to describe the NDH's behavior. ${ }^{37}$ More recently, in The Catholic Church and the Holocaust, Michael Phayer terms Ustaše actions in the NDH "genocide" in his discussion of the Vatican's culpability in Ustaše atrocities perpetrated against Serbs, Jews, and Roma. ${ }^{38}$ It appears clear that Ustaše actions in the Independent State of Croatia did constitute genocide.

\section{The United States Loses a Listening Post}

The rapid and successful German invasion of Yugoslavia on 6 April 1941 forced Lane and the American delegation in Belgrade to vacate the country, leaving the Zagreb consulate as America's only representation in Croatia and, for that matter, in Yugoslavia. But Consul John J. Meily's outpost was not destined to last for long. The Ustaše had no interest in offending their fascist masters by keeping a potential security risk open and running. Croatian authorities were suspicious of the close ties that had existed between the British and American consulates prior to the German invasion and seized this opportunity to prove their mettle. In June 1941, Meily was summoned to the Croatian Foreign Ministry and ordered to close the consulate. The State Department offered no resistance, because Washington did not wish to operate a consulate in a county it did not recognize and was planning to close it voluntarily. Maintaining the consulate could be construed as tacit recognition of the Croatian state, something Washington wished to avoid. In late August and early September, Croatian authorities, with the help of the Italian press, accused Meily, a diplomat sympathetic to Croatian interests, of spying on behalf of the British. Their evidence, based on a few seized American documents, did little more than prove that 
Meily had worked closely with the British, which was certainly no surprise in the days of Lend-Lease. Croatian accusations of espionage were far from valid. This weak attempt to embarrass Washington and ingratiate the NDH with the rest of the Axis never bore fruit. ${ }^{39}$

With no diplomatic ties to Croatia, the United States gained information about the Pavelic regime from various other locations. Ankara and Istanbul became natural centers for information through Turkey's juxtaposition to the Balkans, physically and historically, and its neutrality. The country was teaming with ex-patriates, including a large number of businessmen, and served as a clearinghouse for news and rumor. Neutral Switzerland was another place where information on Croatia arrived, especially on Allan Dulles's desk. Another source used later in the war was operatives of the Office of Strategic Services (OSS). All these outlets proved to be remarkably reliable and detailed in their news gathering and analysis on Pavelić's Croatia. Though rarely closely involved in Croatian affairs, Washington had channels for regular and often trustworthy information.

\section{Washington Learns of the Massacres}

Even with Yugoslavia ripped apart by the Nazi juggernaught, it did not take long for Washington to learn about the atrocities being committed in Pavelić's new state. One of Lane's last telegrams from Belgrade reported that "Serbs and Jews in Zagreb have been ordered to leave portion of city north of Illice Street. All Serbs expelled from government position in Croatia." 40 This message, sent via Budapest, was an indication that Pavelic was following a pattern established by his fascist friends in Germany. In June 1941, a Standard Oil Company employee who had recently left Zagreb offered more evidence of persecutions conducted by the Pavelić regime when he reported to the American delegation in Geneva that "a reign of terror" had descended on Serbs and Jews. ${ }^{41}$ Although he did not mention deaths or executions, he explained that theft and looting were widespread. It was becoming obvious that a very dangerous situation was developing in Croatia.

On 14 August 1941, a letter, accompanied by sixteen pictures, reached the State Department from former Belgrade consul Karl L. Rankin with detailed information about mass executions. Though the number of victims was in dispute and was considered to be a bit "fantastic," it was clear "that many thousands of Serbian civilians [had] lost their lives" at the hands of the Ustaše. ${ }^{42}$ The information presented to the State Department came from an unnamed Serbian government official and was therefore potentially easy to refute as exaggeration and propaganda. The anonymous Serbian official wrote that "we [Serbians] are confronted with a comprehensive policy aiming at the extermination of the Serbian race in the regions in question, which would be preceded by the destruction of the Serbs from an economic standpoint." 43 The author details a series of incidents in which the Ustaše executed Serbs, starting with the first attacks at the end of April in and around Bjelovar. These initial slaughters of Serbs set the tone for the next several months, during which the Ustaše terrorized the Serbian and Jewish populations. Some victims were slaughtered not by gunshot but in an almost animal-like fashion, with hammers and knives, their bodies hacked into pieces. Death by bullet may have been a welcome relief. The author reports that others were killed by hand grenades. Special attention, the writer notes, was given to the persecution and execution of Orthodox priests and former Yugoslav politicians. This highly detailed document includes the names of individuals executed by the Ustaše. The author even mentions the establishment of a concentration camp in Koprivnica. ${ }^{44}$ Rankin thought 
that the information was of great value and suggested that "more publicity regarding atrocities which the Germans are permitting, and which are possible only because of the German conquest and dismemberment of Yugoslavia, would be helpful to the Serbian and Allied cause." 45 Rankin's advice was not accepted by the State Department.

Rankin's report came on the heels of a missive from King Peter, then in exile, to Roosevelt that also addressed the horrors taking place in Croatia. Obviously moved by news of the massacres, Roosevelt asked his secretary of state, Cordell Hull, whether Peter's letter should be made public. Unfortunately, Hull recommended that it be kept private and that the White House inform the young king that the president had given the letter his full attention. ${ }^{46}$ This silence did nothing to draw notice to the tragedy taking place in Croatia. If anything, by not making a strong, official statement, the US government enabled zealots for Croatian independence within the United States to insist that the executions and massacres were nothing but Serbian and Jewish propaganda. Likewise, the lack of an official statement only fanned the flames of hatred among Serbian Americans. Without a doubt, domestic peace between Croatian and Serbian Americans played a major role in the government's decision, but the atrocities were so outrageous that it boggles the imagination that any country could or would keep news of them silent.

Even with the above information in hand, Hull and the State Department refused to appreciate the scope of what was happening. Only once did the State Department inquire about the NDH's policy toward Serbs. On 29 September 1941, Hull asked the American embassy in Rome to investigate reports of "mass deportations of Serbs from Croatia." 47 There is no record of a response from Rome, but Hull's lone question, in spite of the letters and reports already received by the State Department and those that would pour into Washington later, signified a sense of disinterest as well as skepticism in Washington. In Hull's and the State Department's defense, they were dealing with numerous reports of mass killings and what would later come to be called genocide; it was difficult to separate the incidents in Croatia from those taking place in other corners of the globe. Hull's lack of curiosity, however, deserves particular emphasis, especially because information about the slaughter of Serbs and Jews by the Ustaše streamed into the State Department throughout the war. Beginning in 1942, regular status reports on Croatia were sent to the State Department by Samuel Honaker, the American consul general in Istanbul, and similar officials. These detailed and remarkably accurate documents, supplemented with information from Bern, all paint the same picture: Pavelic and the Ustaše had slaughtered thousands of Serbs and Jews, terrorized the countryside, and, in the process, tried to erase any Serbian heritage from Croatia by destroying Orthodox churches and forcing conversions to Catholicism.

Although it was difficult to ignore this consistent drumbeat of information, nonintervention in foreign affairs had been a theme in the State Department during the 1920s and 1930s. Even in Latin America, an arena where the United States had made numerous intrusions prior to World War I, Washington chose to avoid direct intervention in the interwar years. Underpinning non-intervention was the "fear that insidious alien influences were endangering America's unique institutions." 48 The ideology of nativism, most clearly enunciated in the National Origins Act of 1924, continued to influence American domestic and foreign policy. Roosevelt was another factor: he was suspicious of the State Department and never granted officials, including the secretary of state, much latitude in expanding the role of American foreign policy. ${ }^{49}$ Although often chafing under Roosevelt's leadership style, most 
officials in the State Department had a narrow view of the country's role in international affairs and were not eager to change it, especially when dealing with Croatia. Yugoslavia was a distant place, believed by most in the State Department to be primarily an area of British interest, far removed from American consciousness. ${ }^{50}$ Only later in World War II, after the most vicious period of atrocities had passed, did the United States begin to play as large a role in Yugoslavia as the British did. The State Department's inaction can be explained also by its concern over keeping the peace between Serbian and Croatian Americans, as well as by an undercurrent of antiSemitism. ${ }^{51}$

In part, the blame for America's slow and restrained response rests not with the State Department but on the shoulders of the Yugoslav government-in-exile. Wracked by dissension between Croat and Serb members, it failed to spread the word of Pavelić's murderous spree. Too often Serb and Croat politicians only emphasized their ethnicity and jockeyed for position to gain the best deal possible for their particular nationality at the war's conclusion. Again the Ustaše's atrocities became a political football. Many Croatians in the government were unwilling to proclaim the truth about Pavelić's murderous regime, mainly because their desire for an independent Croatia led them to ignore the slaughter. Croatians in the exiled Yugoslavian government believed that recognizing the NDH's crimes would place Croatian interests in an unfavorable light at war's end. Demanding that the horrors be proclaimed from the highest mountain, Serbs, such as Konstantin Fotic, often incorrectly castigated all Croatians as murderers. Serb nationalists hoped that information about Ustaše atrocities would help justify some of the abusive policies favored by the Serbian-dominated Yugoslavian government prior to the war. Since Yugoslavism was a rare bird, most attempts to draft statements damning the NDH's actions were sabotaged. ${ }^{52}$

Regardless of the exiled government's problems, by early 1942 there were too many reports detailing the atrocities for there to be any doubt that genocide was taking place. Accounts from various sources-all repeating the same major themes, some with more detail than others-were hard to ignore. For example, an account from a "neutral businessman" who left Croatia in September 1941 states that the Ustaše had run roughshod over the country, terrorizing and murdering Serbs. This businessman, a resident of Croatia, noted that some sources claimed that 250,000 Serbs had been slaughtered, a figure exaggerated at this point in the war. "These mass killings took place mostly in the country, where Ustasi armed bands went from village to village and deliberately tried to exterminate every Serb." 53 In major cities, Serbs had "almost disappeared," having been forced into concentration camps, ghettoized, or deported. The same treatment had been dispensed to the NDH's Jews: "They have been murdered and beaten, sent to concentration camps, herded into railway trucks by the hundred and allowed to die en route from starvation and exposure."54

Even with a wealth of information at hand, Roosevelt's attention was far from the activities in the NDH. When young King Peter visited the United States in the summer of 1942, he delivered to Roosevelt another account of some of the atrocities committed on Pavelić's watch. According to Fotić, the Yugoslav government-in-exile's representative in the United States, the president was "shocked at the details of Ustashi massacres." 55 Croatian activities, however, were so far from Roosevelt's mind that Fotic, a Serbian nationalist, had to remind him that the NDH was at war with the United States. At that moment, "the President raised his hands in surprise and said that he had almost forgotten about that." 56 Speaking more directly about war crimes, Roosevelt told Peter 
that he would make sure the Ustaše realized that they would have to pay for their crimes at the end of the war, something that, in fact, would happen only in rare cases. More pointedly, Roosevelt explained that "he would try especially to impress 'this man Pavelićh." " 57 Roosevelt's comment screamed ignorance of Pavelić's personality and his movement. The president's inattention is somewhat understandable, but his glaring ignorance of the situation in Croatia is surprising. Fotic responded to Roosevelt by noting that the United States could say little that would affect Pavelić.

In light of Roosevelt's remarks, it is not surprising that the president never urged Pope Pius XII to put pressure on Pavelić to end the Ustaše's genocide. It is obvious that other wartime matters occupied the president and took precedence over events in Croatia. Myron Taylor, however, had a good relationship with the pontiff and could have raised the issue of Croatian atrocities with him. As US representative to the Vatican, Taylor, in 1942, asked the papacy to speak out about Axis atrocities. As he did throughout the war, Pius XII only made indirect comments about the genocidal acts being committed by the Nazis and their satellite states. ${ }^{58}$ Since the Vatican enjoyed a close relationship with the NDH, and Pius XII had held two audiences with Pavelić by the end of 1942, there was at least a possibility that American pressure on the Vatican might have elicited a few words of restraint in Zagreb. Unfortunately, this opportunity was missed.

One member of the government was deeply concerned with the NDH's atrocities. Roosevelt's minister to the Yugoslav government-in-exile, A.J. Drexel Biddle, Jr., was fed a diet of reports from the royalist Ćetnik leader Draža Mihailović, who was waging a halting guerilla campaign against the Nazis. These reports were of varying accuracy and quality, because the exiled government and Mihailovic wanted Washington to believe that they were the only legitimate force waging war against the Germans. Biddle, one of Roosevelt's close friends, was told by the government-in-exile that the $\mathrm{NDH}$ had killed about 600,000 Serbian men, women, and children as of September 1942-an exaggerated figure, designed to attract American attention, but not completely out of the ballpark. Another 300,000 had reportedly been forced out of their homes. Regardless of the numerical accuracy of these reports, exterminations were indeed taking a crushing toll, especially in ethnically diverse Bosnia. ${ }^{59}$

With so much evidence, including the publication of Martyrdom of the Serbs by the Orthodox Church of the United States and Canada, a book that vividly detailed the Ustaše's crimes, there was no way for the American government to question the scope of the atrocities being committed in the NDH. ${ }^{60}$ An Office of War Information (OWI) document from August 1943 underscores Washington's concern about relations between Serbian and Croatian Americans, explaining that Martyrdom of the Serbs had the capacity to generate greater disturbances between these two ethnic groups by tarnishing all Croatians as supporters of Ante Pavelić and the Ustaše. Interestingly, the OWI did not question the validity of the publication, noting that "so far as is known many of these charges are true" and declaring that "the Ustashi...set out to exterminate the Serbs of Croatia." ${ }^{61}$ The evidence of wholesale slaughter, carried out in the most despicable fashion, was abundant. Pictures of decapitations, bludgeonings, and mutilations, followed by detailed reports of the extinction of villages, were not a closely kept secret. Despite the wealth of information documenting genocidal events, the US government made few comments. The White House and the State Department were concerned about domestic unrest between Serbian and Croatian Americans as a byproduct of Pavelićs actions in Croatia and decided on a strategy of silence as the best course. In this way, Roosevelt could avoid offending either nationality while charging 
the OWI, the government body responsible for monitoring America's various nationalities, with keeping both Croatian and Serbian Americans united in their opposition to Nazi Germany. ${ }^{62}$

\section{The Public Learns of Genocide}

The American public, outside of Serbian- and Croatian-American circles, did not learn of the Croatian atrocities until 11 October 1941, when a short item appeared on page 3 of the New York Times stating that the Ustaše had murdered 300,000 to 340,000 Serbs and pro-Yugoslav Croatians. Citing intelligence reports from agents in Croatia and Bosnia, the anonymous reporter explained that "nearly 5,000 Serbs were slaughtered by Croatian Ustashi in a concentration camp outside Yatovo [probably Jadovno]"; 63 the article describes specific atrocities, some with inflated numbers. This report of thousands of deaths failed to register with the American public, however; there was little to no reaction. For most Americans, content with isolationism, Yugoslavia was a faraway speck on the map with little relevance to American interests. This genocide seemed distant to Americans, who were trying to enjoy their long Indian summer outside of the war.

The American responsibility to address this genocide increased dramatically after Germany declared war on the United States. Hitler's foolish declaration of war on 11 December 1941 mandated that Pavelić follow suit. The poglavnik, always loyal to his fascist controllers, declared war on the United States and its Allies on 15 December. This action had the potential to cause ethnic unrest in several American cities, for the United States was home to the largest Croatian population in the world outside of Croatia. Likewise, the declaration made it difficult for Pavelic to draw much financial, diplomatic, or moral support from Croatian Americans, who now had to choose sides in the conflict. Pavelić's significant recruiting and media efforts in the United States during the 1930s would never pay the immense dividends he and his supporters desired. The cause of Croatian independence had lost most of the sympathy traditionally allotted by Americans to nationalities seeking independence; instead, Croatia was viewed as part of Hitler's Europe, having sold its soul for a chance at a patina of independence within the fascist world.

With much bigger concerns in the Pacific Theater, the United States paid little attention to Pavelić's declaration; it received, for example, no more than one paragraph in the New York Times. What damage could Croatia do to American interests? Would American forces face Croatian troops in battle? Pavelić's announcement was recognized, rightly, as the action of a pawn.

In early 1942, evidence of Croatian atrocities continued to mount with the publication of a report, issued by the archbishop of the Serbian Orthodox Church, stating that more than 180,000 people had been killed by the Ustaše prior to early August. ${ }^{64}$ This document, featuring many grisly details, was forwarded to the US government, where it was received as authoritative. Nevertheless, government officials and the media did little more than read the archbishop's report.

Even at this point, there were no public statements from the White House or the State Department about the executions and tortures taking place in Croatian concentration camps or about the vast number of indiscriminate murders. One of the first confirmable reports of major concentration camps came on 9 March 1942 in a telegram from Bern. The Wiener Tageblatt had reported that Croatia had spent $120,000,000$ kuna to establish "work camps." Jasenovac was specifically mentioned as housing 1,050 people, mostly Jews, who were well treated. ${ }^{65}$ This veneer of legitimacy 
was transparent to anyone in the State Department who followed affairs in the Third Reich. Unfortunately, the news never reached the American public.

Finally Roosevelt realized that a public declaration was needed to define America's position on these and other Axis atrocities. This was especially true because evidence of odious activities, as well as rumors, many being reported in Serbian and Croatian newspapers in the United States, was mounting. After receiving a letter from King Peter II that discussed atrocities being inflicted in Yugoslavia, Roosevelt requested that some action be taken to "compel the enemy to discontinue this ruthless slaughter" and asked that the men responsible for these crimes face justice at some later date. The president decided to make a public declaration pledging that those who had committed atrocities would be held responsible for their actions. As Biddle said, "The President plainly wants to publish something [a response to the atrocities]-including King Peter's letter." 66 Knowing that the State Department would favor making a minimal statement, if any at all, Biddle sagely added that "in dealing with atrocities you do not try to be courteous, or diplomatic, or nice. The subject matter requires that it be handled with punch."67 The State Department was wary of taking unilateral action on war criminality, preferring to make a statement in cooperation with other Allied states. Although Peter's letter of 22 July was the second time the Yugoslav government had made a request for an American statement on Yugoslav war crimes-the first being on 13 April 1942 - the State Department suggested that the White House only produce a statement in cooperation with the other major Allies. ${ }^{68}$ The State Department carried the day. Roosevelt's reply to King Peter promised to collect evidence of war crimes so that war criminals could be brought to justice at the end of the conflict. His response, however, did not go as far as the king had requested and included little more than vague promises. ${ }^{69}$

In a public statement, the White House pledged that those who had committed war crimes would be held responsible for their actions:

The perpetrators of these crimes against civilization can no longer be dealt with merely as units of the national guilt of the Axis powers. Guilt is personal; and the men, as individuals, who have thus violated, and who continue to violate the most elementary rules of civilization, must be held personally accountable. When the time comes-as come it will-justice must be done, and civilized law must be vindicated. ${ }^{70}$

These were welcome words; but the statement does not mention Croatia or Yugoslavia by name. Instead, it was designed as a very general statement on atrocities, carefully worded so as not to offend any of the Allies or to be a future impediment to united Allied action against atrocities. Such a statement was a far cry from what King Peter had hoped for.

The wording of this announcement and others-such as that 7 October 1942, which declared that war criminals would be tried before courts at the end of the war-did presage the Moscow Declaration's Statement on Atrocities, agreed upon by the Big Three in October 1943. These documents did not mention that quislings and war criminals from Nazi satellites would be punished, although the Allies resolved to pursue German war criminals and try them for war crimes at the end of the conflict. The omission was unfortunate, and certainly it disappointed Serbs and Serbian Americans.

\section{America's Domestic Concerns}

Although a public statement directly damning NDH atrocities was not to be had, the deaths in Croatia did serve to influence some government action against Pavelić's sympathizers in the United States. There was deep concern in many government 
departments and in the White House that Pavelićs activities in Croatia would foment unrest between Serbian and Croatian Americans. This was all the more important because many of these immigrants worked in manufacturing sectors that were critical to the war effort. Most Croatian and Serbian-Americans were members of the working class and lived in close proximity to one another in industrial cities such as Pittsburgh, Youngstown, Akron, Chicago, and Detroit. Serbian-Americans were dismayed, shocked, and full of rage when news of Ustaše atrocities reached the United States. The American Srbobran, the largest and oldest Serbian newspaper in the United States, reported Pavelić's crimes in great detail beginning on 4 November 1941. In light of the news from Croatia, the paper moved toward a staunchly Serbian nationalist position, heavily criticizing Pavelić's regime and Croatians in general. American authorities determined that many Serbs had seized on Pavelić's killing spree as an excuse to favor a Greater Serbia at the end of the war. This was a rather cynical way of looking at the changing Serbian position, although it did have a certain level of truth. The strong condemnation of Pavelić, and of Croatians in general, came as no surprise, considering the magnitude of the news being reported. ${ }^{71}$ After reading about the deaths of family members and friends at the hands of the Ustaše, Serbian fraternal organizations and newspapers unsurprisingly took a harsh anti-Croatian position, laced with a strong dose of Serbian nationalism.

Prior to the birth of the NDH, there was little direct animosity between Serbian and Croatian Americans, except on the part of fringe elements. The Ustaše's crimes changed this. It was fortunate for American interests that the Pittsburgh newspaper Nezavisna Hrvataska Država ("Independent State of Croatia"), a Pavelić mouthpiece established in the 1930s, found it more and more difficult to follow its pro-Pavelić line as news from Yugoslavia drifted back to the United States. Before World War II, the Post Office, the State Department, and the Justice Department repeatedly attempted to close the paper, without success. After Pavelic declared war on the United States, however, the paper, under the leadership of Luka Grbic since 1938, was forced to close its doors in March $1942 .^{72}$ Its demise was beneficial to the American war effort, since otherwise this fervently pro-Pavelić newspaper would have done nothing but fuel ethnic hatred. But small numbers of Croatian Americans sympathetic to Pavelić continued to spread their views. In early 1942, the FBI raided Domobran organizations, fraternal groups established by Ustaše operatives in the 1930s, and effectively drove a number of Pavelić supporters underground. Although none of the key Domobran members were arrested, J. Edgar Hoover had made his point; fifth columnists would not exist in the United States. ${ }^{73}$

An outspoken advocate of Pavelić throughout the 1930s, Ante Došen, as the highestprofile Pavelić operative in the United States, required special attention and had been arrested in 1941 by US Immigration officials. Došen had been active for years, organizing support for Pavelić among Croatian-American communities and raising money to fund Pavelić and his Ustaše operations in Europe. Seemingly always able to avoid the government's clutches, he successfully delayed the prosecution of his case and obtained letters of support from both US senators representing Pennsylvania. ${ }^{74}$ Clearly frustrated by the Došen case, an OSS agent very familiar with Pavelić sympathizers in the United States remarked that,

Regardless of our constitutional rights, this man should not receive the benefits of said rights which he has flagrantly violated for years... Even if this man is convicted on illegal entry and a technical charge of perjury, he still would not receive just punishment. $^{75}$ 
The United States was unable to get any charges to stick to Došen. As late as the 1970s, he was living in New York City.

Interested in identifying and locating Axis supporters or sympathizers, the OWI and the FBI believed that the Croatian Catholic Union (CCU), headquartered in Gary, Indiana, had pro-Pavelić members. Articles appearing in its weekly paper, Nasa Nada ("Our Hope"), gave the impression that the organization was at least in favor of Croat separatism and at most pro-Pavelić. As early as 1941, there was evidence that the CCU was opposed to any criticism of Pavelic, or even of Hitler, on the grounds that Nasa Nada was not a political newspaper. Francis X. Kolander, the paper's editor, condemned Pavelić's declaration of war against the United States and was reprimanded by George Rakić, the CCU's president and one of its founders. Kolander was warned not to print articles expressing opposition to Pavelic again. ${ }^{76}$ In May 1942, the FBI recognized that the CCU had "never issued any statement condemning the present Quisling government of Dr. Ante Pavilćh in Croatia."77 To no one's surprise, the FBI became interested in removing the CCU's board of directors from their positions, since they deemed them to be dangerous Nazi sympathizers operating under the aegis of Ante Pavelić. ${ }^{78}$ In the fall of 1942, Kolander was defeated for re-election to his post as editor of Nasa Nada, partly because he had "openly condemned ... Pavelić for having declared a state of war against the United States."79 Later, Kolander, who had a son fighting in the US Army, produced a letter written by Nasa Nada's new editor, Monsignor M.G. Domladovac, that described the sentiments of some in the CCU:

Whatever PAVELIĆ may be, he at least has freed Croatians from Serbian chain. That he is not a traitor ... is seen from the fact that neither Hitler nor Mussolini believe him, because Pavelić's children and wife are as hostages in Italy so that Hitler and Mussolini have a guarantee... Therefore: As American citizens we are bound to help our new fatherland in its war, but no one can force us to condemn anyone in the old fatherland until we know the TRUE situation in the old country. ${ }^{80}$

Monsignor Domladovac's comments are interesting, if a bit delusional. Although the evidence against Pavelić was becoming mountainous, the editor refused to condemn him and, incongruously, sought to support both America and Croatia in their war efforts, even though Croatia was at war with the United States.

Both the OWI and the OSS were aware of the activities of Došen and Domladovac, but their concerns went beyond these two figures. Reverend Ivan Stipanovic of Youngstown, Ohio, and Ivan Krešić, editor of Hrvatski List $i$ Danica Hrvatska ("Croatian Gazette and Croatian Morning Star"), attracted interest because of their staunch and public support for Pavelić. Stipanović served as president of the newly formed Supreme Council of American Croats, the heir to the dormant Domobran cells that Branimir Jelić, a key Pavelić operative, and his followers had worked so hard to establish. ${ }^{81}$ The actions and beliefs of Stipanovic and Domladovac were symbolic of how Pavelić's message had infiltrated Croatian Catholic leadership within the United States, particularly among Franciscans. Both men were so obsessed with establishing an independent Croatia that they became blind to the horrors occurring in the NDH. Hatred of Serbia, combined with intense nationalism and a romantic view of Croatia, dictated their thoughts and actions. ${ }^{82}$

As Croatian and Serbian rhetoric escalated, Yugoslavian politicians in the United States became sources of controversy. Konstantin Fotic was accused of "whipping up anti-Croat sentiment." 83 Others believed that Momcilo Ninčić, the Yugoslav foreign minister, was "the chief instigator of this Greater Serbia campaign." "T4 The State 
Department and the FBI believed that such accusations could elevate Serbian and Croatian rivalry to the point of seriously damaging the American war effort. At the State Department, Wallace Murray was fearful of what ethnic rivalry-or "hyphenisms," as ethnic groups were often called-would do to the United States if a strong American identity was not accepted by new immigrants. "I hope I am wrong," he wrote,

but I have the uneasy feeling that we are storing up serious trouble for ourselves in the future by permitting the propagation of bitter controversial questions among foreign residents and foreign-born American citizens in this country. ${ }^{85}$

The battles between Serbian and Croatian newspapers reached such a boiling point that Elmer Davis, in charge of the OWI, held a meeting with editors of some of the more influential papers to explain that they had to suspend their "quarreling." Davis, and the State Department in general, believed that the newspapers were creating "a danger to the American war effort." ${ }^{66}$ Fortunately, the division between Serbs and Croats never did damage the American war machine, partly because most Serbian- and Croatian-Americans favored the reestablishment of a Yugoslavia at the war's end or were largely apathetic with respect to events in the old country. These immigrants had become Americans.

Though small numbers of Croatian Americans pledged allegiance to Pavelić, the vast majority remained fervently loyal to America's cause and implacable enemies of the Axis. As we have seen, Croatian Americans were torn between favoring Yugoslavism, supporting an independent Croatia sanctioned by the United States and Western Europe, or settling for Pavelić's state. The OWI worked tirelessly to convince Croatian Americans that their first allegiance must be to the United States. As Davis noted while speaking before the Croatian Conference on 19 September 1942, "no American citizen can have more than a secondary interest in what government is workable in the old country. One thing we can be sure of is that (the future Jugoslavia problem) will be solved there by people rather than by people in this country." 87 The OWI's chief concern was to unite Serbian and Croatian Americans in the crusade against the Axis. Dissent between the two would only harm the war effort, as Davis emphatically explained at a meeting of Slavic leaders held in the State Department on 18 September $1942 .{ }^{88}$

Croatian organizations in the United States made an appeal to meet on 20-21 February 1943 in Chicago to proclaim just such sentiments. In their call for action, these prominent mainstream Croatian-American organizations clearly demonstrated support for the United States and condemned Pavelic. They proclaimed that "those who follow Pavelich are baiting Croatians against the Serb people" and maintained that Pavelić and Serbian strongman Milan Nedic were "heirlings" of Hitler and Mussolini. ${ }^{89}$ They went so far as to call Pavelić a bandit. Delegates were careful, however, to mention the Ustaše's atrocities only vaguely. This is understandable, but regrettable, as a clear denunciation of Pavelić's crimes would probably have won them a great deal of respect from the American government and the grudging esteem of Serbian-American groups. This meeting was followed in September 1943 by the Sixth Convention of the Croatian Fraternal Union (CFU), the largest Croatian organization in America, at which Croatian representatives pledged their loyalty to the United States and their devotion to the war effort while rejecting Pavelic and his movement. ${ }^{90}$ Although there were varying political positions on both right and left in the CFU, it was becoming clear that very few Croatian Americans could support Pavelić's policies, regardless of whether or not there was an independent Croatia. Only obsessively 
nationalistic and ardently anti-Communist groups such as the CCU were willing to tolerate Pavelić's regime.

\section{Roosevelt and Croatia's Future}

The NDH's atrocities, however, were an important influence on Allied views of a postwar Yugoslavia. Considering the horrific events, could Croats and Serbs live peacefully in a reunited Yugoslavia, or was separation the only viable answer? Roosevelt hinted at his opinion of post-war Yugoslavia as early as October 1942, in a meeting with Fotić. Sympathetic with the Serbs and fond of their young king, Roosevelt informed the ambassador that Serbian desires were paramount, considering their commitment to the Allied cause. Roosevelt did not oppose the continuation of Yugoslavia; instead, he wished for South Slavs to determine their fate without its being dictated to them by Western powers. ${ }^{91}$ These opinions were suitably vague, for the early part of the war, to allow Roosevelt to alter his views as events dictated.

The president's opinions had shifted somewhat by early 1943. In a meeting with Anthony Eden and Harry Hopkins, Roosevelt contended that the Croats and Serbs had virtually nothing in common and that the concept of reuniting them in one state was "ridiculous." Roosevelt believed that Serbia deserved to emerge as an independent state, while Croatia would exist under a trusteeship of some sort. All of this had the obscurity of casual conversation. Influenced to some extent by the Yugoslavian government-inexile, Eden thought that Yugoslavia could exist again with Croat and Serb side by side. ${ }^{92}$ Post-war Yugoslavian affairs were far from the president's main concern. In discussions surrounding the Moscow Declaration, which dealt with holding war criminals responsible for their crimes at the end of the war, little was said about Yugoslavia's ultimate fate. The president merely reiterated his position that "Croatia may have to be set up separately from Serbia."93 Neither Britain nor the United States believed that Tito would forge a united Yugoslavia under his star power and the Communist banner.

Interestingly, the regular situation reports on Croatia that littered State Department files appear to have had only limited effect in altering the views of the White House. From these documents, it was obvious that Pavelić and the Ustaše had ravaged the country, annihilated its economy, and destroyed tens of thousands of lives. The reports made for interesting reading, but they were largely ignored by both the White House and the State Department.

\section{Conclusion}

American information about $\mathrm{NDH}$ atrocities was exceptionally and surprisingly accurate and detailed. A mere two weeks after the horrific assaults on Serbs began, the US State Department had reliable evidence that atrocities were occurring. Although the evidence mounted as weeks turned into months, and it became clear that the Ustaše's assaults had expanded to include the Jewish population as well, neither the White House nor the State Department ever uttered a public word specifically condemning the NDH's actions. Regardless of appeals by King Peter, silence remained. American authorities did issue statements condemning atrocities, but only in vague and almost neutral terms. Likewise, neither the State Department nor President Roosevelt made any effort to pressure the Vatican to counsel restraint in the NDH. Although it is far from certain that American pressure would have influenced the Vatican to act, it is certain that no such attempt was made. In part, the lack of response was because the State Department considered Croatia-and Yugoslavia, 
for that matter - a British region of influence, distant from American interests. Only in the months prior to the German invasion had the United States directed attention to Yugoslavia. The White House and the State Department concerned themselves with the more significant states in Europe, paying only modest attention to the wide-scale atrocities being committed in Croatia.

This case study of American response to a lesser-known genocide illustrates the complex issues that governments face when confronting such atrocities. It is tempting to offer stern criticism of American inaction on this issue; however, the genocide did move policy makers to action in the United States. US authorities were quick to realize that atrocities in the NDH had the capacity to elevate friction between Croatian and Serbian Americas. This concern was very real to the OWI, the FBI, the White House, and the State Department, and each of these agencies focused on keeping the American war effort moving forward while preventing any fifth-column elements from emerging. A detailed public statement from the White House or the State Department condemning Pavelić's actions might have served only to increase ethnic tensions in the United States, and speaking out on NDH atrocities would have meant making statements on all ethnicities under assault by fascist regimes. Most likely, such a "bidding war" would only have led to greater ethnic tension in the country. The State Department was convinced that any statement on wartime atrocities needed to be made in cooperation with the Allies. It was deemed best to allow the OWI to monitor Serbian-American and Croatian-American newspapers and organizations, urging them to moderate their nationalism-laced views. The OWI stressed to both Croatianand Serbian-American communities that their allegiance was to the United States and not to Croatia or Serbia. Likewise, the FBI was used to squelch the pro-Pavelic forces that had been active in the country since the early 1930s. In this manner, the genocide in Croatia had a direct effect on US domestic policy decisions. In the final analysis, although genocide was perpetrated in Croatia, American authorities remained silent, choosing instead to make exceedingly pragmatic decisions designed to maintain a peaceful and productive war effort.

\section{Notes}

1. National Microfilm Archive Publication (NAMP) M1203, roll 16, 860J.00/1289, telegram, MacMurray to Secretary of State, 6 May 1941.

2. There is heated debate over the exact number of Serbs, Jews, and Roma killed by the Ustaše, with nationalism permeating and exaggerating statistics. Since many records are missing, it is very difficult to obtain precise figures devoid of bias. The statistics given here are those recognized by the United States Holocaust Memorial Museum as the best available at this time.

3. Historians have all but ignored the US government's response to Ustaše violence. Bits of information may be found in various works, such as Mark Aarons and John Loftus, Unholy Trinity: The Vatican, the Nazis, and the Swiss Banks (New York: St. Martin's Press, 1989); George J. Prpic, The Croatian Immigrants in America (New York: Philosophical Library, 1971); Joseph Kraja, "The Croatian Circle, 1928-1946: Chronology and Reminiscences," Journal of Croatian Studies 5-6 (1964-1965): 145-204, but no comprehensive study exists.

4. There are numerous sources of excellent quality on the complicated political scene in Yugoslavia in the late 1920s and early 1930s. See John R. Lampe, Yugoslavia as History: Twice There Was a Country (Cambridge: Cambridge University Press, 1996); Aleksa Djilas, The Contested Country: Yugoslav Unity and Communist Revolution, 1919-1953

(Cambridge, MA: Harvard University Press, 1991); Jill A. Irvine, The Croat Question:

Partisan Politics in the Formation of the Yugoslav Socialist State (Boulder, CO: Westview 
Press, 1993); Marcus Tanner, Croatia: A Nation Forged in War (New Haven, CT: Yale University Press, 1997); L.S. Stavrianos, The Balkans Since 1453 (New York: Holt, Rinehart and Winston, 1958).

5. There is considerable debate as to when the Ustaše was established. While 7 January 1929 may not be the exact date, the Ustaše appears to have been in existence by the end of that month.

6. Dimitrije Djordjevic, "Fascism in Yugoslavia: 1918-1941," in Native Fascism in the Successor States, 1918-1945, ed. Peter Sugar, 125-34 (Santa Barbara, CA: ABC Clio, 1971), 131-33; Ivan Avakumovic, "Yugoslavia's Fascist Movements," in Native Fascism in the Successor States, 1918-1945, ed. Peter Sugar, 135-43 (Santa Barbara, CA: ABC Clio, 1971), 139-42.

7. Ante Pavelić, Errori e orrori, comunismo e bolscevismo in Russia e nel mondo (Varese: Instituto per gli studi di politica internazionale, 1941).

8. Vladko Maček, In the Struggle for Freedom, trans. Elizabeth Gazi and Stjepan Gazi (University Park: Pennsylvania State University Press, 1957), 245.

9. For a detailed discussion of Italian-Croatian relations see H. James Burgwyn, Empire on the Adriatic: Mussolini's Conquest of Yugoslavia, 1941-1943 (New York: Enigma Books, 2005), 8-16. Also see James J. Sadkovich, Italian Support for Croatian Separatism, 1927-1937 (New York: Garland, 1987).

10. Anthony Cave Brown, The Last Hero: Wild Bill Donovan (New York: Times Books, 1982), 152-56.

11. Telegram to Arthur Bliss Lane from the Acting Secretary of State, 27 March 1941, quoted ibid., 969 .

12. Ibid.

13. Ulrich von Hassell, The Von Hassell Diaries, 1938-1944 (London: Hamish Hamilton, 1948), 160.

14. The Nazis hoped that Vladko Maček would take the reigns of the new Croatian state. Being an outspoken opponent of the Nazis, however, Maček refused the post.

15. Srdja Trifković, Ustaša: Croatian Separatism and European Politics, 1929-1945 (London: The Lord Byron Foundation for Balkan Studies), 139-41. Also see Raphael Lemkin, Axis Rule in Occupied Europe (New York: Carnegie Endowment for International Peace, 1944), 620-26.

16. Lemkin, Axis Rule, 626-27.

17. N. Dinko Šuljak, Croatia's Struggle for Independence: A Documentary History (Arcadia, CA: Croatian Information Service, 1977), 177.

18. Ibid.; Also see Trifković, Ustaša, 139.

19. Hrvatski List, quoted in Richard West, Tito and the Rise and Fall of Yugoslavia (New York: Carroll \& Graf, 1994), 88.

20. Jonathan Steinberg, All or Nothing: The Axis and the Holocaust, 1941-1943 (London: Routledge, 1990), 30.

21. The USHMM possesses a significant and moving collection of photographs and records documenting this type of Ustaše behavior. Some evidence is also found in the National Archives in Washington and in the Public Record Office in London.

For an excellent examination of Ustaše methods and atrocities see Jozo Tomasevich, War and Revolution in Yugoslavia, 1941-1945 (Stanford, CA: Stanford University Press, 2001).

22. Constantin Fotitch, The War We Lost: Yugoslavia's Tragedy and the Failure of the West (New York: Viking Press, 1948), 121-22.

23. Edmond Paris, Genocide in Satellite Croatia, 1941-1945 (Chicago: American Institute for Balkan Affairs, 1961), 127-35. Also see Vladimir Dedijer, The Yugoslav Auschwitz and the Vatican: The Croatian Massacre of the Serbs during World War II (Buffalo, NY:

Prometheus Books, 1992).

24. Richard West, "Death Camp Capture Revives Croat Shame," The Sunday Telegraph, 7 May 1995. 
25. Harriet Pass Freidenreich, The Jews of Yugoslavia: A Quest for Community (Philadelphia: Jewish Publication Society of America, 1979), 191-92; United States Holocaust Memorial Museum, Historical Atlas of the Holocaust (New York: Macmillan, 1996), 171-77. Also see John F. Morley, Vatican Diplomacy and the Jews during the Holocaust, 1939-1943 (New York: Ktav Publishing, 1980), 147-65, Raul Hilberg, The Destruction of the European Jews, vol. 2 (New York: Holmes \& Meier, 1985), 708-18; and Leni Yahil, The Holocaust: The Fate of European Jewry, 1932-1945 (New York: Oxford University Press, 1987), 429-31.

26. This issue is brilliantly examined in Donald Bloxham, The Great Game of Genocide: Imperialism, Nationalism, and the Destruction of the Otttoman Armenians (Oxford: Oxford University Press, 2005).

27. The most significant example is Franjo Tudgman, Bespuca povijesne zbijlnosti (Zagreb: Matica Hrvatska, 1990). Formerly a partisan and a general in the Yugoslav army, Tudjman served as president of Croatia. Also see Ljubo Boban, "Jasenovac and the Manipulation of History," East European Politics and Societies 4 (1990): 580-92.

28. Pavelić's reputation has been restored among some in Croatia, especially young men. It is not uncommon to see men sporting tattoos featuring the Ustaše $U$, or pictures of Pavelic or Ustaše symbols in popular bars.

29. For a fine examination of how Serbs and Croatians have mythologized their history and used it to inspire conflict in the 1990s, see David Bruce MacDonald, Balkan Holocaust? Serbian and Croatian Victim-Centred Propaganda and the War in Yugoslavia (Manchester, UK: Manchester University Press, 2002).

30. Convention on the Prevention and Punishment of the Crime of Genocide, 9 December 1948, 78 U.N.T.S. 277, http://www.unhchr.ch/html/menu3/b/p_genoci.htm (accessed 4 January 2008).

31. The literature on this topic is vast. A good introduction is Samuel Totten, William S. Parsons, and Israel W. Charny, ed., A Century of Genocide: Critical Essays and Eyewitness Accounts (London: Routledge, 2004). Excellent and more specialized works include Robert Gellately and Ben Kiernan, Mass Murder in Historical Perspective (Cambridge: Cambridge University Press, 2003), and Frank Chalk and Kurt Jonassohn, The History and Sociology of Genocide: Analyses and Case Studies (New Haven, CT: Yale University Press, 1990).

32. For a discussion of defining genocide see Leo Kuper, Genocide: Its Political Use in the Twentieth Century (New Haven, CT: Yale University Press, 1981); Ben Kiernan, "Twentieth Century Genocides: Underlying Ideological Themes from Armenia to East Timor," in The Specter of Genocide: Mass Murder in Historical Perspective, ed. Robert Gellately and Ben Kiernan, 29-51 (Cambridge: Cambridge University Press, 2003); Robert Melson, "Paradigms of Genocide: The Holocaust, the Armenian Genocide, and Contemporary Mass Destructions," Annals of the American Academy of Political and Social Science 548 (1996): 156-68; and Helen Fein, Accounting for Genocide: National Responses and Jewish Victimization during the Holocaust (New York: Free Press, 1979), among many other works.

33. Edmond Paris, Genocide in Satellite Croatia, 1941-1945 (Chicago: American Institute for Balkan Affairs, 1961).

34. John A. Armstrong, "Collaborationism in World War II: The Integral Nationalist Variant in Eastern Europe," The Journal of Modern History 40 (1968): 396-410, 408.

35. Fein, Accounting for Genocide, 103.

36. Kuper, Genocide, 89.

37. Bette Denich, "Dismembering Yugoslavia: Nationalist Ideologies and the Symbolic Revival of Genocide," American Ethnologist 21 (1994): 367-90; Robert Hayden, "Recounting the Dead: The Rediscovery and Redefinition of Wartime Massacres in Late- and PostCommunist Yugoslavia," in Memory and Opposition under State Socialism, ed. Rubie S. Watson, 167-84 (Santa Fe, NM: School of American Research, 1993), 176-77; Michael Sells, "Kosovo Mythology and the Bosnian Genocide," in In God's Name: Genocide and Religion in the Twentieth Century, ed. Omer Bartov and Phyllis Mack, 180-205 (New York: Berghahn Books, 2001), 185. 
38. Michael Phayer, The Catholic Church and the Holocaust, 1930-1965 (Bloomington: Indiana University Press, 2000), 31-41.

39. "Illegal Act Charged to U.S. Aide in Croatia," New York Times, 31 August 1941, 11:3; "Espionage Is Charged to U.S. Aide in Croatia," New York Times, 1 September 1941, 6:4; "U.S. Consul Is Accused Again in the Italian Press," New York Times, 4 September 1941, 14:5.

40. NAMP M1203, roll 19, 860H.01/328, telegram, Arthur Bliss Lane to Secretary of State, 17 May 1941.

41. NAMP M1203, roll 16, 860H.00/1304, telegram, Boucher to Secretary of State, 7 June 1941.

42. NAMP M1203, roll 16, 860H.00/1322, letter, Consul K.L. Rankin to Secretary of State, 14 August 1941.

43. Enclosure, ibid.

44. Ibid.

45. Rankin to Secretary of State, ibid.

46. Walter R. Roberts, Tito, Mihailović and the Allies, 1941-1945 (Durham, NC: Duke University Press, 1987), 19. For more on King Peter's wartime experiences see Peter II, A King's Heritage: The Memoirs of King Peter II of Yugoslavia (London: Cassell, 1955).

47. NAMP M1203, roll 16, 860H.00/1327CF, letter, Cordell Hull to American Embassy in Rome, 29 September 1941.

48. Robert Dallek, The American Style of Foreign Policy: Cultural Politics and Foreign Affairs (New York: Oxford University Press, 1983), 113.

49. Robert Dallek, "Roosevelt as Foreign Policy Leader," in FDR and the Holocaust, ed. Verne W. Newton, 41-51 (New York: St. Martin's Press, 1996), 42-45.

50. Vladimir Petrov, A Study in Diplomacy: The Story of Arthur Bliss Lane (Chicago: Henry Regency, 1971), 104.

51. For a discussion of anti-Semitism in the State Department see Henry L. Feingold, The Politics of Rescue: The Roosevelt Administration and the Holocaust, 1938-1945 (New Brunswick, NJ: Rutgers University Press, 1970); Richard D. Breitman and Alan M. Kraut, "Anti-Semitism in the State Department: Four Case Studies," in Anti-Semitism in American History, ed. David A. Gerber, 167-97 (Urbana: University of Illinois Press, 1986).

52. Fotitch, The War We Lost, 116-18. Also see Walter R. Roberts, Tito, Mihailovic and the Allies, 1941-1945 (New Brunswick, NJ: Rutgers University Press, 1973); Stevan K.

Pavlowitch, "Out of Context: The Yugoslav Government in London, 1941-1945," Journal of Contemporary History 16 (1981): 89-118.

53. NAMP M1203, roll 16, 860H.00/1331, "Conditions in Croatia," memo from G. Wadsworth in Rome, 2 December 1941.

54. Ibid.

55. Fotitch, The War We Lost, 179.

56. Ibid.

57. Ibid., 179-80.

58. George Bull, "The Vatican, the Nazis and the Pursuit of Justice," International Affairs 47 (1971): 353-58, 356. Also see John S. Conway, "Myron C. Taylor's Mission to the Vatican, 1940-1950," Church History 44 (1975): 85-99; Anthony Rhodes, The Vatican in the Age of the Dictators, 1922-1945 (New York: Holt, Rinehart \& Winston, 1974).

59. Letter to the Secretary of State from A.J. Drexel Biddle, Jr., 9 September 1942, in Foreign Relations of the United States, 1942, Europe, 812-13 (Washington: US GPO, 1961).

60. Serbian Orthodox Church, Diocese for the United States and Canada, Martyrdom of the Serbs (Chicago: Palandech's Press, 1943). This work is littered with grisly photographs and contains numerous eyewitness accounts.

61. National Archives and Records Administration (NARA), RG 208, Entry 222, Box 1082, "Serbian Extremist Propaganda in the United States," OWI memo, 25 August 1943.

62. NARA, RG 208, Box 1070. The Paul Sturman Papers at the Dwight D. Eisenhower Library include several documents that emphasize the OWI's desire to reduce tensions between Serbian and Croatian Americans.

63. "Massacres Laid to Croat Ustashi," New York Times, 11 October 1941, 3:6. 
64. James MacDonald, "Serbian Prelate Charges Killing of 180,000 in Nazi-Invaded Croatia," New York Times, 3 January 1942, 8:6.

65. NAMP M1203, roll 16, 860H.00/1376, telegram, Huddle to Secretary of State, 9 March 1942.

66. NAMP M1203, roll 16, 860H.00/1404 1/2, letter, A.J. Biddle, Jr., to Mr. Atherton, 31 July 1942.

67. Ibid.

68. NAMP M1203, roll 16, 860H.00/1404 1/2, Department of State memo, 30 July 1942.

69. Telegram to King Peter II from President Roosevelt with Enclosure, 3 August 1942, in Foreign Relations of the United States, 1942, Europe, 806 (Washington: US GPO, 1961)

70. NAMP M1203, roll 16, 860H.00/14041/2, "Statement of the President of the United States," n.d.

71. NAMP M1203, roll 20, Department of State memo, "Regarding the Serb-Croat Dispute," 27 May 1942.

72. Ibid. Also see George J. Prpić, The Croatian Immigrants in America (New York: Philosophical Library, 1979), 296-98.

73. Prpić, ibid., 298.

74. OSS memo, "Re: Ante Doshen," 31 March 1942, http://www.pavelićpapers.com/documents/ oss/oss001.html (accessed 20 February 2006). State Department records from the 1930s offer a large cache of documents outlining concerns about the activities of Došen and other Pavelić operatives in the United States, including Branimir Jelić. See NAMP M1203, roll 4.

75. Ibid.

76. OSS memo, "Axis Propagandists within the Croatian Catholic Union," 9 May 1942, http://www.pavelićpapers.com/documents/oss/oss005.html (accessed 21 February 2006).

77. FBI Memo, 3 May 1942, obtained under the Freedom of Information Act by Jon Levy.

78. Ibid.

79. NARA, RG 208, Entry 221, Box 1070, letter, Francis X. Kolander to Mr. Elmer Davis, 3 October 1942.

80. NARA, RG 208, Entry 221, Box 1070, letter, Rt. Rev. Msgr. M.G. Domladovac to Mr. John Birek.

81. Jere Jareb, Političke uspomene i rad dra Branimira Jelića (Cleveland, OH: Mirko Samija, 1982), 86-97. Also see Jure Krišto, "Čuvari svoje braće: policijsko nagledanje amerićkih Hrvata tijekom Drugoga svjetskoga rata," Časopis za suvremenu povijest (2003): 408-14.

82. NAMP M1203, roll 20, 860H.01/486, "Foreign Nationality Groups in the United States," memo, Foreign Nationalities Branch to Director of Strategic Services, 6 May 1943.

83. NAMP M1203, roll 19, 860H.01/396, State Department memo by Wallace Murray, 6 July 1942.

84. NAMP M1203, roll 16, 860H.00/1402 1/2, State Department memo, 25 June 1942.

85. NAMP M1203, roll 19, 860H.01/396, State Department memo by Wallace Murray, 6 July 1942.

86. NAMP M1203, roll 17, 860H.00/1417, State Department memo by A.A. Berle, Jr., 25 September 1942.

87. Quoted in Paul Sturman Papers, Dwight D. Eisenhower Library, Box 4, File 3, OWI memo, Paul Sturman to Alan Cranston, with enclosure, 1 February 1943.

88. Ivan Čizmić, History of the Croatian Fraternal Union of America, 1894-1994 (Zagreb: Goldent, 1994), 278.

89. Sturman to Cranston, 1 February 1943.

90. Čizmić, History, 281.

91. Fotitch, The War We Lost, 189-90. Also see Ilija Jukić, The Fall of Yugoslavia, trans. Dorian Cooke (New York: Harcourt Brace Jovanovich, 1974), 132.

92. Robert E. Sherwood, Roosevelt and Hopkins: An Intimate History (New York: Harper \& Brothers, 1948), 708-11; Jukić, The Fall of Yugoslavia, 168.

93. Foreign Relations of the United States, 1943, vol. 1, General (Washington: US GPO, 1963), 543. 